\title{
Catastrophe Mechanism of Stress-Fissure Coupling Field in Mining Close Distance Seams in Southwest China
}

\author{
Suo Jie, ${ }^{1}$ Li Zhen-hua $\mathbb{D}^{2,3}$ Huang Cun-han, ${ }^{2,3}$ Cao Zheng-zheng, ${ }^{2,3}$ Xu You-lin, ${ }^{4}$ \\ and Chen $\mathrm{Zu}$-guo ${ }^{5}$ \\ ${ }^{1}$ School of Geoscience and Technology, Southwest Petroleum University, Chengdu, 610500 Sichuan, China \\ ${ }^{2}$ School of Energy Science and Engineering, Henan Polytechnic University, Jiaozuo, 454000 Henan, China \\ ${ }^{3}$ Collaborative Innovation Center of Coal Work Safety and Clean High Efficiency Utilization, Jiaozuo, 454000 Henan, China \\ ${ }^{4}$ Institute of Mining Engineering, Guizhou Institute of Technology, Guiyang, 550003 Guizhou, China \\ ${ }^{5}$ Xintian Coal Mine, Yonggui Energy Development Co., Ltd., Qianxi, 551500 Guizhou, China
}

Correspondence should be addressed to Li Zhen-hua; jzlizhenh@163.com

Received 23 April 2021; Revised 22 May 2021; Accepted 19 July 2021; Published 2 August 2021

Academic Editor: Kai Yao

Copyright (c) 2021 Suo Jie et al. This is an open access article distributed under the Creative Commons Attribution License, which permits unrestricted use, distribution, and reproduction in any medium, provided the original work is properly cited.

\begin{abstract}
For the sake of studying the catastrophe mechanism of stress-fissure coupling field in mining close distance seams in southwest China, a test working face in Guizhou province in southwest China is adopted and researched by the methods of numerical calculation and similar experiment. When the working face advances to $180 \mathrm{~m}$ in $4 \#$ coal seam in a similar experiment, the overlying rock breaks to the central base plate of Yulongshan limestone, and the conductive fractures run through the Changxing limestone karst cave and Yulongshan limestone karst cave. When the 1402 working face advances to $350 \mathrm{~m}$, the top of vertical karst caves in the middle of the model produces extrusion damage, forming a penetrating water inrush passage. When the 1402 working face advances to $480 \mathrm{~m}$, the top slab of the working face comes under periodic weighting with the short step. Besides, the mining of 9\# coal seam starts after $4 \#$ coal seam in mining close distance seams. When the working face in $9 \#$ coal seam advances to $340 \mathrm{~m}$ in numerical simulation, the maximum opening of the overburden fractures is $51.16 \mathrm{~mm}$. The fractures in the roof are mainly caused by the periodic breaking and falling of the basic roof, connected with the floor fractures of 4 \# coal seam. When the working face in $9 \#$ coal seam advances to $500 \mathrm{~m}$, the maximum opening of the overburden fracture is $93.09 \mathrm{~mm}$. Specifically, as the working face advances, the opening of fracture in the roof after collapse of the basic roof periodically is mainly greater than $5 \mathrm{~mm}$, and the compaction closure is mainly $1 \mathrm{~mm}-5 \mathrm{~mm}$. The fractures in the gob floor are mainly $0.1 \mathrm{~mm}-1 \mathrm{~mm}$, and the fracture opening of the collapsed rock mass in the gob is mainly $1 \mathrm{~mm}-5 \mathrm{~mm}$ and greater than $5 \mathrm{~mm}$. The karst caves in the overburden reduce the periodic weighting step of working face and play a guiding role in the direction of fracture development and water inflow passage formation. The karst caves are connected to surface waterfall holes and trap pits, and atmospheric precipitation recharges the water in the caves. The research results can be treated as an important basis for the prevention and treatment for water inrush disaster in mining close distance seams in the karst area of southwest China.
\end{abstract}

\section{Introduction}

China is one of the countries with the most extensive karst distribution and the close distance seams in the world [1]. Meanwhile, China has the largest coal mining production in the world [2]. Therefore, there are many coal mines in the karst area in China [3]. However, the ecological environment of the karst mining area is fragile [4]. The underground mining of coal seam causes rock strata movement and induces the development of mining-induced fractures of karst caves in the overburden, which has a great impact on the ecological balance in the karst area [5,6]. Specifically, the water inrush disaster is easily induced in the downward mining in close distance seams in the karst mining area. For example, the water inrush disasters in downward mining caused by karst caves occurred in the Xintian coal mine in 
Guizhou province, which greatly affected the safety mining production $[7,8]$. Therefore, it is of great significance to research the evolution mechanism of water inrush passage in the overburden induced by karst caves in downward mining, in order to guarantee the safe mining in the karst mine area.

The scholars at home and aboard have carried out lots of research on the evolution mechanism of water inrush passage in the overburden induced by mining. Liu et al. [9] researched the mechanism of the karst water burst and its prevention countermeasures in Yuanliangshan tunnel systematically, which shows that the karst water burst in tunnels is a gradually developed process, influenced by water pressure, different filling materials, and the plastic zones around the tunnel. Zhao et al. [10] established a nonlinear model of coupled seepage-pipe flows to study the change of flow state of water inrush of confined karst cave, with the introduction of the equivalent hydraulic conductivity of pipe flow for the water inrush of confined karst cave. Jiao et al. [11] investigated the mechanism of delayed groundwater inrush from a covered karst cave in coal seam floor through the analysis of the formation of karst cave with special environment and physical process, in order to prevent the delayed groundwater inrush occurring from a covered karst cave in coal seam floor in north China coalfield. Zhao et al. [12] established the linkage analysis between fluid-solid coupling and strength reduction method of water bursting from concealed confined karst cave before roadway, on the basis of fluid-solid coupling theory of water bursting from confined karst cave and strength reduction method of rock pillar to prevent water inrush. Zhu et al. [13] established four kinds of a generalized model of the overlying rock cave collapse, respectively, under the action of mining; meanwhile, it was mainly analyzed on the basis of the conceptual model of the causes for the collapse caused by the mining. Pan et al. [14] applied a self-developed new type of model test system to the solid-fluid coupling model tests on lagging water-inrush of karst cave and revealed the variation of the multifield information such as displacement, stress, and seepage pressure effectively. Wang et al. [15] established a frustum model for the instability of tunnel face considering the influences of the location and size of the cavern on the stability of the intermediate rock wall, in order to study the bearing capacity and failure mode of the intermediate rock wall in the presence of orthogonal high-pressure caverns in front of horseshoe tunnels. Zhu et al. [16] built the model of mining under karst caves and analyzed the stratum movement law and the failure characteristics of karst caves, in order to study the development law of mining-induced fracture and its influences on fracture development of karst caves when mining in karst area.

The above research results are focus on the evolution mechanism of water inrush passage in the overburden induced by mining, which provide the significant reference for safe and high-efficiency mining [17-20]. In consideration of the wide spread of close distance seams and karst zone in a mining area in China, the disastrous mechanism of stress-fissure coupling field and prevention for water inrush in close distance seams have not been revealed recently. Therefore, it is obvious that the catastrophe mechanism of stress-fissure coupling field in mining close distance seams in southwest China has not been researched systematically and deeply $[21,22]$. Based on the mining and geological condition of 1402 working face in Xintian coal mine in Guizhou province, the catastrophe mechanism of stress-fissure coupling field in mining close distance seams in southwest China is studied, by the physical similarity experiment and numerical calculation simulation. The research results can be treated as an important basis for the prevention and treatment for water inrush disaster in mining close distance seams in the karst area of southwest China.

\section{Physical Similarity Experiment for Water Inrush Passage Evolution}

2.1. Physical Similarity Model. The 1402 working face in the Xintian coal mine has a strike length of $147 \mathrm{~m}$ and a dip length of $1148 \mathrm{~m}$. The single strike longwall mining method is adopted for coal mining. The main coal seams are $4 \#$ coal seam and 9\# coal seam. The mining heights of two coal seams are $4 \mathrm{~m}$ and $3 \mathrm{~m}$, and the mining depths are $262 \mathrm{~m}$ and $294 \mathrm{~m}$, respectively. According to the geological and mining conditions of the 1402 working face in the Xintian coal mine, there are five large karst caves arranged in the overburden rock in Figure 1, marked as $1 \#$ cave, $2 \#$ cave, $3 \#$ cave, $4 \#$ cave, and 5\# cave. Specifically, $1 \#$ cave and 2\# cave are on the left side in physical similarity experiment, and $1 \#$ cave is above $2 \#$ cave; and 5\# cave are in the right side in physical similarity experiment, and there are $3 \#$ cave and $4 \#$ cave in the middle position from left to right in physical similarity experiment. Meanwhile, the shape characteristics of $1 \#$ cave and 2\# cave are horizontal caves from top to bottom, and $3 \#$ cave is a combination of the longitudinal cave and inclined cave, $4 \#$ cave is a vertical cave, and $5 \#$ cave is a combination of the horizontal cave, vertical cave, and inclined cave. The spatial position of $1 \#$ cave and $2 \#$ cave are distributed vertically; besides, $1 \#$ cave, $3 \#$ cave, $4 \#$ cave, and $5 \#$ cave are distributed horizontally.

In order to study the spatial and temporal evolution of the mining-induced fracture of Changxing formation chert and the Yulong section chert during the mining of $4 \#$ coal seam, physical similarity experimental research for water inrush passage evolution is carried out. The basic physical and mechanical parameters of each rock formation are shown in Table 1, based on the comprehensive histogram of the working face and relevant experiments. The physical similarity model is left with $60 \mathrm{~m}$ protective coal pillars on the left and right boundaries. The mining direction is from left to right, with 2 hours interval between each mining.

2.2. Experiment Results. When the 1402 working face advances to $180 \mathrm{~m}$, the overlying rock breaks to the central base plate of Yulongshan limestone, the conductive fractures run through the Changxing limestone karst cave and Yulongshan limestone karst cave, and the delaminations occur between the central and lower Yulongshan limestone. Large damage occurs to the near-horizontal bead-like karst 


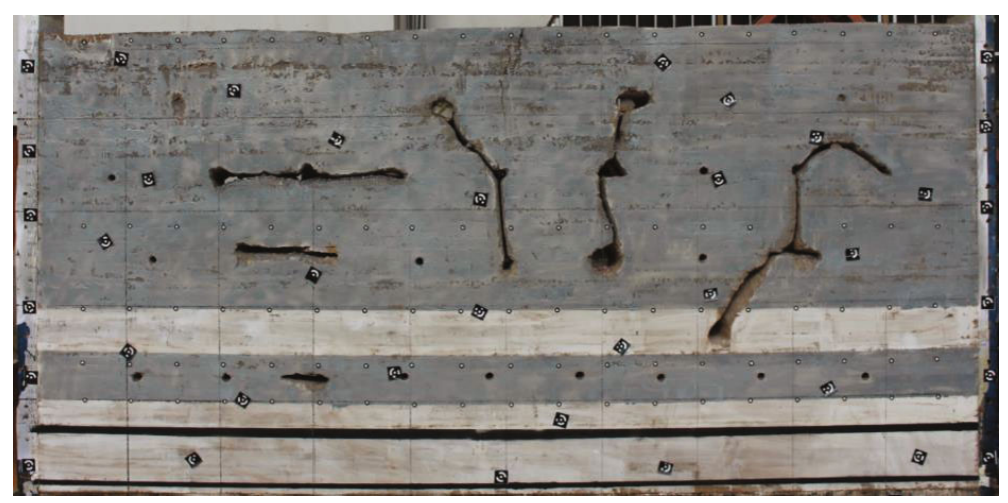

FIgURE 1: Physical similarity model.

TABle 1: Physical and mechanical properties of rock mass.

\begin{tabular}{|c|c|c|c|c|c|c|c|c|c|}
\hline No. & Lithology & $\begin{array}{l}\text { Height } \\
\text { (m) }\end{array}$ & $\begin{array}{c}\text { Buried } \\
\text { depth (m) }\end{array}$ & $\begin{array}{l}\text { Density } \\
\left(\mathrm{kg} / \mathrm{m}^{3}\right)\end{array}$ & $\begin{array}{l}\text { Volume } \\
\text { modulus } \\
(\mathrm{GPa})\end{array}$ & $\begin{array}{c}\text { Shearing } \\
\text { modulus (GPa) }\end{array}$ & $\begin{array}{c}\text { Internal } \\
\text { friction angle } \\
\left(^{\circ}\right)\end{array}$ & $\begin{array}{c}\text { Internal } \\
\text { cohesion } \\
(\mathrm{MPa})\end{array}$ & $\begin{array}{c}\text { Tensile } \\
\text { strength } \\
(\mathrm{MPa})\end{array}$ \\
\hline 1 & Limestone & 180 & 183 & 2800 & 3.06 & 2.39 & 42 & 6.53 & 5.70 \\
\hline 2 & Marl & 15 & 198 & 2750 & 2.27 & 1.56 & 38 & 4.43 & 3.53 \\
\hline 3 & Mudstone & 12 & 210 & 2670 & 1.48 & 0.65 & 28 & 2.14 & 1.38 \\
\hline 4 & Limestone & 30 & 240 & 2800 & 3.06 & 2.39 & 42 & 6.53 & 5.70 \\
\hline 5 & Siltstone & 10 & 250 & 2840 & 1.94 & 0.90 & 33 & 2.65 & 2.10 \\
\hline 6 & $\begin{array}{l}\text { Muddy } \\
\text { siltstone }\end{array}$ & 3 & 253 & 2770 & 2.50 & 1.16 & 35 & 3.15 & 2.31 \\
\hline 7 & Siltstone & 5 & 258 & 2840 & 1.94 & 0.90 & 33 & 2.65 & 2.10 \\
\hline 8 & 4\# coal & 4 & 262 & 1500 & 1.18 & 0.55 & 34 & 1.56 & 1.12 \\
\hline 9 & $\begin{array}{l}\text { Muddy } \\
\text { siltstone }\end{array}$ & 6 & 268 & 2770 & 2.50 & 1.16 & 35 & 3.15 & 2.31 \\
\hline 10 & Mudstone & 4 & 272 & 2670 & 1.48 & 0.65 & 28 & 2.14 & 1.38 \\
\hline 11 & Siltstone & 3 & 275 & 2800 & 2.78 & 1.28 & 37 & 3.64 & 2.25 \\
\hline 12 & Siltstone & 6 & 281 & 2840 & 1.94 & 0.90 & 33 & 2.65 & 2.10 \\
\hline 13 & $\begin{array}{l}\text { Fine-grained } \\
\text { sandstone }\end{array}$ & 4 & 285 & 2800 & 2.78 & 1.28 & 37 & 3.64 & 2.25 \\
\hline 14 & Siltstone & 6 & 291 & 2840 & 1.94 & 0.90 & 33 & 2.65 & 2.10 \\
\hline 15 & 9\# coal & 3 & 294 & 1500 & 1.18 & 0.55 & 34 & 1.56 & 1.12 \\
\hline 16 & Siltstone & 3 & 297 & 2840 & 1.94 & 0.90 & 33 & 2.65 & 2.10 \\
\hline
\end{tabular}

cave located in the lower part. Large damage occurs in the near-horizontal bead-like karst cave located in the lower part. The right-hand boundary of the karst cave is subjected to tensile stress and the rupture surface develops upwards along the right-hand boundary of karst caves, with a small amount of rock at the top of the lateral karst cave collapsing into the karst cave. The central and upper parts of the Yulongshan section are disturbed and remain in a stable structure, as shown in Figure 2.

When the 1402 working face advances to $290 \mathrm{~m}$, the overburden fractures continue to develop upwards, reaching the top of Yulongshan limestone and forming two fracture faces. Due to the guiding effect of karst caves on the expansion of the fractures, the through-fracture surface on the side of the opening cut passes through the beaded karst caves in the middle of Yulongshan limestone. There is a vertical karst cave on the upper left side of 1402 working face, which is skewed to the left side of the model by a certain angle, and runs through the upper, middle, and lower parts of the limestone in the Yulongshan section. The gushing fractures enter at the bottom of the karst cave and penetrate at the top, creating a rupture surface, as shown in Figure 3.

When the 1402 working face advances to $350 \mathrm{~m}$, the top of vertical karst caves in the middle of the model produces extrusion damage. The limestone on the top of the cave collapses, and the bottom is subjected to tensile stress to produce open fractures, forming a penetrating water inrush passage. Due to the continuous compaction of broken rocks in the mined-out area, the broken rock layer further revolves and descends, and the conduction fractures behind the minedout area are gradually closed by squeezing, as shown in Figure 4 . 


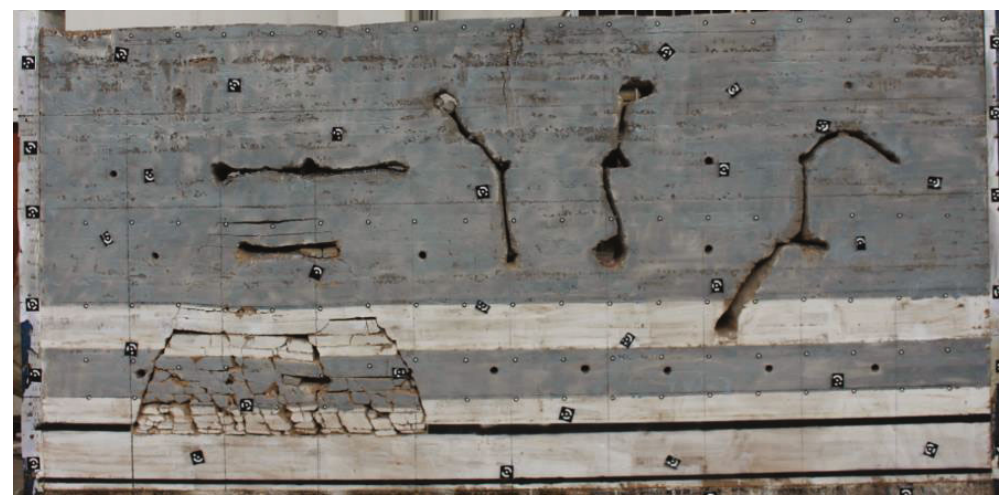

Figure 2: Water inrush passage in the overburden (mining distance is $180 \mathrm{~m}$ ).

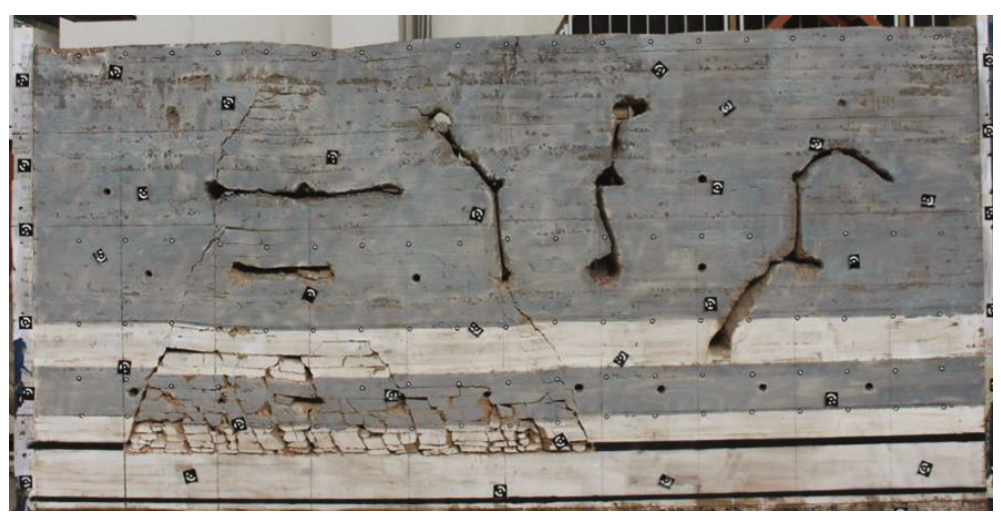

FIGURE 3: Water inrush passage in the overburden (mining distance is $290 \mathrm{~m}$ ).

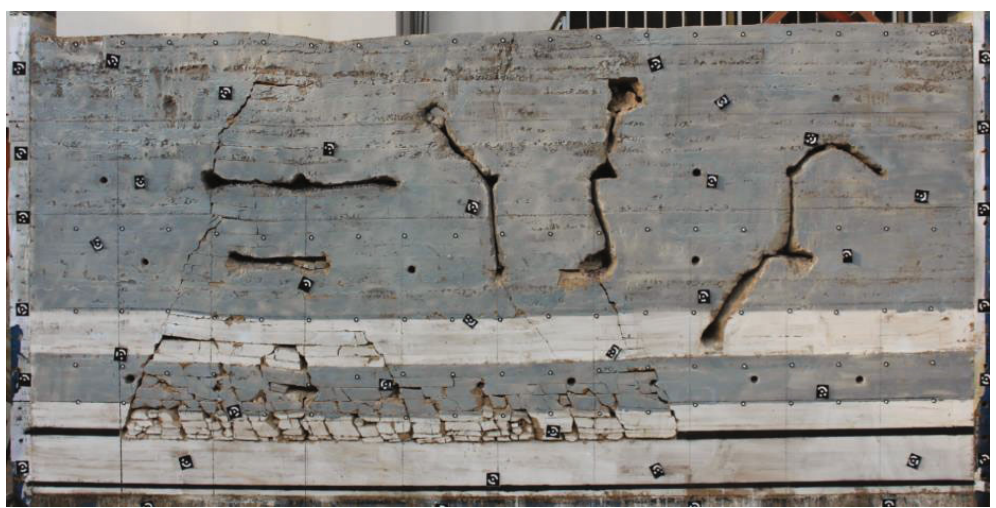

FiguRE 4: Water inrush passage in the overburden (mining distance is $350 \mathrm{~m}$ ).

The periodic weighting is the roof pressure phenomena caused by the periodical collapse of the basic roof in the fractured zone. When the 1402 working face advances to $480 \mathrm{~m}$, the top slab of the working face comes under periodic weighting with the short step. The large stress concentration causes a shear break downwards at the boundary of the central part of the cavern. The cavern in the middle of Changxing limestone has a guiding effect on the development of the fractures so that the fractures pass through the rounded cavern of the Changxing limestone up to the top of the working face. When the trapezoidal fractured rock comes into con- tact with the mined-out area, the overburden stresses are further transferred to the mined-out area, and eventually, the overburden as a whole forms a stable structure, as shown in Figure 5.

It is obvious that karst caves play a guiding role in the direction of fracture development and water inflow passage formation. The water inflow passage develops from bottom to top, and when it develops to a certain height, it expands towards the karst caves and, finally, leads to the karst caves. When the fractures are sufficiently developed, the conductive fractures tend to be formed between two caves. 


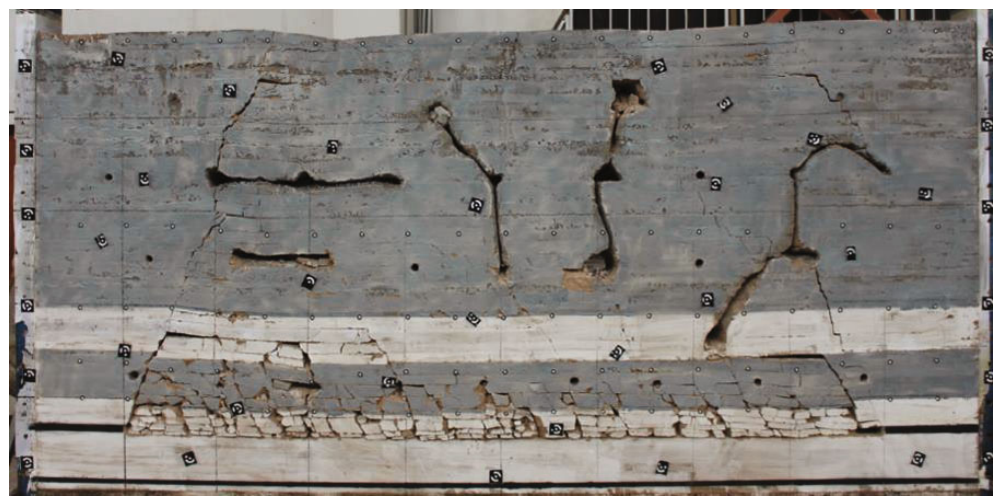

FiguRE 5: Water inrush passage in the overburden (mining distance is $480 \mathrm{~m}$ ).

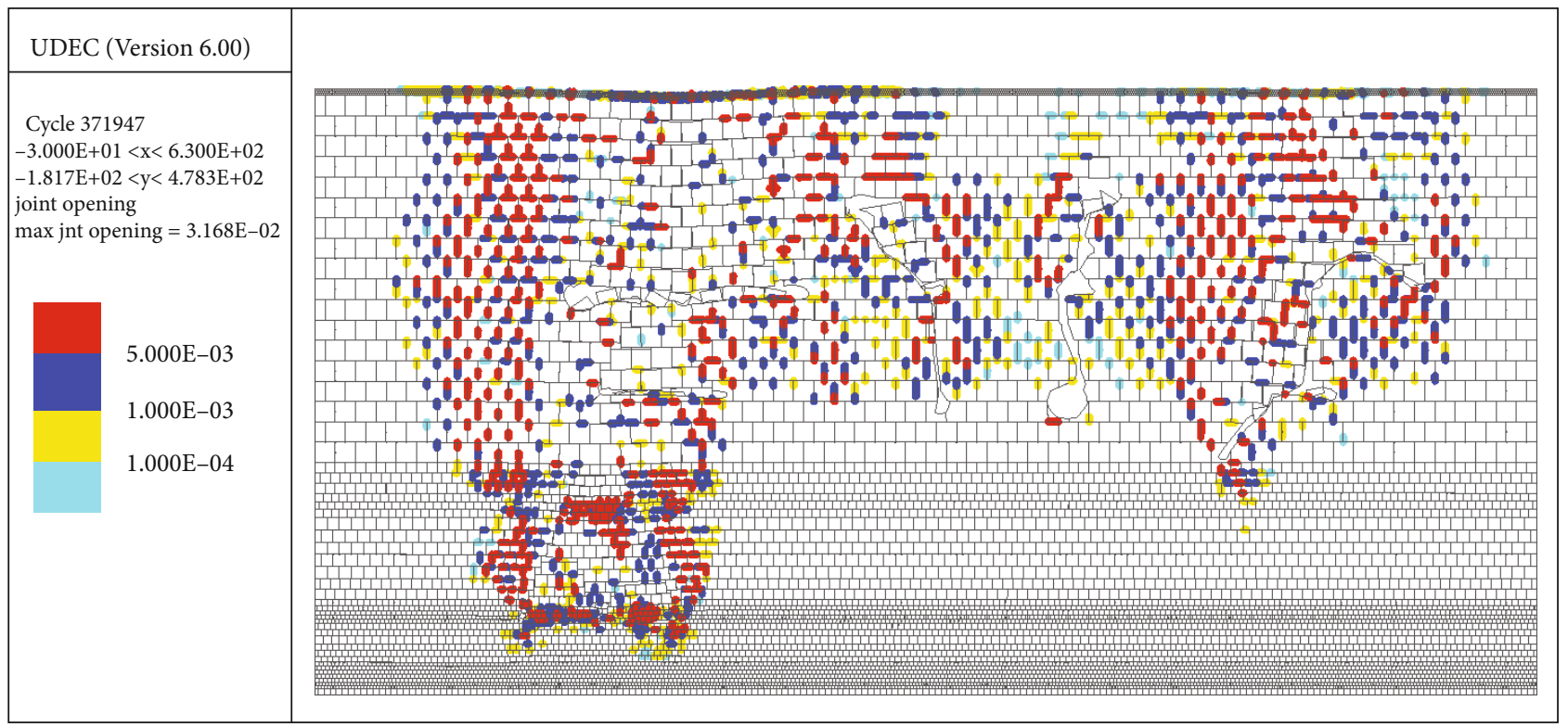

Figure 6: Mining-induced fracture field (mining distance is $180 \mathrm{~m}$ in 4\# coal seam).

\section{Numerical Calculation Simulation for Water Inrush Passage Evolution}

The evolution of the mining-induced fracture field of the cavernous overburden at the 1402 working face is researched by numerical calculation simulation in this section, and the scheme is designed by downward mining, namely, the $4 \#$ coal seam in mined firstly, followed by mining the 9\# coal seam. The numerical simulation model is established in UDEC numerical software, on the basis of the mining geological conditions of 1402 working face, with five karst caves in the overburden. The Mohr-Coulomb model is chosen as the constitutive model, and the Coulomb slip model of surface contact is chosen as the joint constitutive model. The length and the height of the numerical model are $600 \mathrm{~m}$ and $297 \mathrm{~m}$, respectively. The mining heights of $4 \#$ coal seam and $9 \#$ coal seam are $4 \mathrm{~m}$ and $3 \mathrm{~m}$, and the mining depths are $262 \mathrm{~m}$ and $294 \mathrm{~m}$, respectively. The left and right boundary in the numerical simulation model is the fixed horizontal velocity boundary condition, and the bottom boundary in the numer- ical simulation model is the fixed vertical velocity boundary condition. The advance length in $4 \#$ coal is $400 \mathrm{~m}$, and each step is $20 \mathrm{~m}$; besides, the advance length of 9 \# coal seam is $400 \mathrm{~m}$, and each step is $20 \mathrm{~m}$. The evolution law of the fracture field during each mining process is analyzed.

3.1. Mining-Induced Fracture Field in 4\# Coal Seam. When the working face in $4 \#$ coal seam advances to $180 \mathrm{~m}$, the mining-induced fracture field in the overburden is shown in Figure 6. The maximum opening degree of the fracture is $31.68 \mathrm{~mm}$. The fractures in the overlying roof of the working face are mainly concentrated at the front and rear ends of the stope, and the fracture opening is mainly greater than $5 \mathrm{~mm}$. The fractures in the stope floor are mainly $0.1 \mathrm{~mm}-1 \mathrm{~mm}$. After the collapsed rock mass in the gob is compacted, the fracture opening is mainly greater than $1 \mathrm{~mm}$.

Specifically, the fracture opening greater than $5 \mathrm{~mm}$ is mainly used to analyze the penetration characteristics of water inrush passage between overlying karst caves. The 1\# cave and 2\# cave have a thorough connection. The 


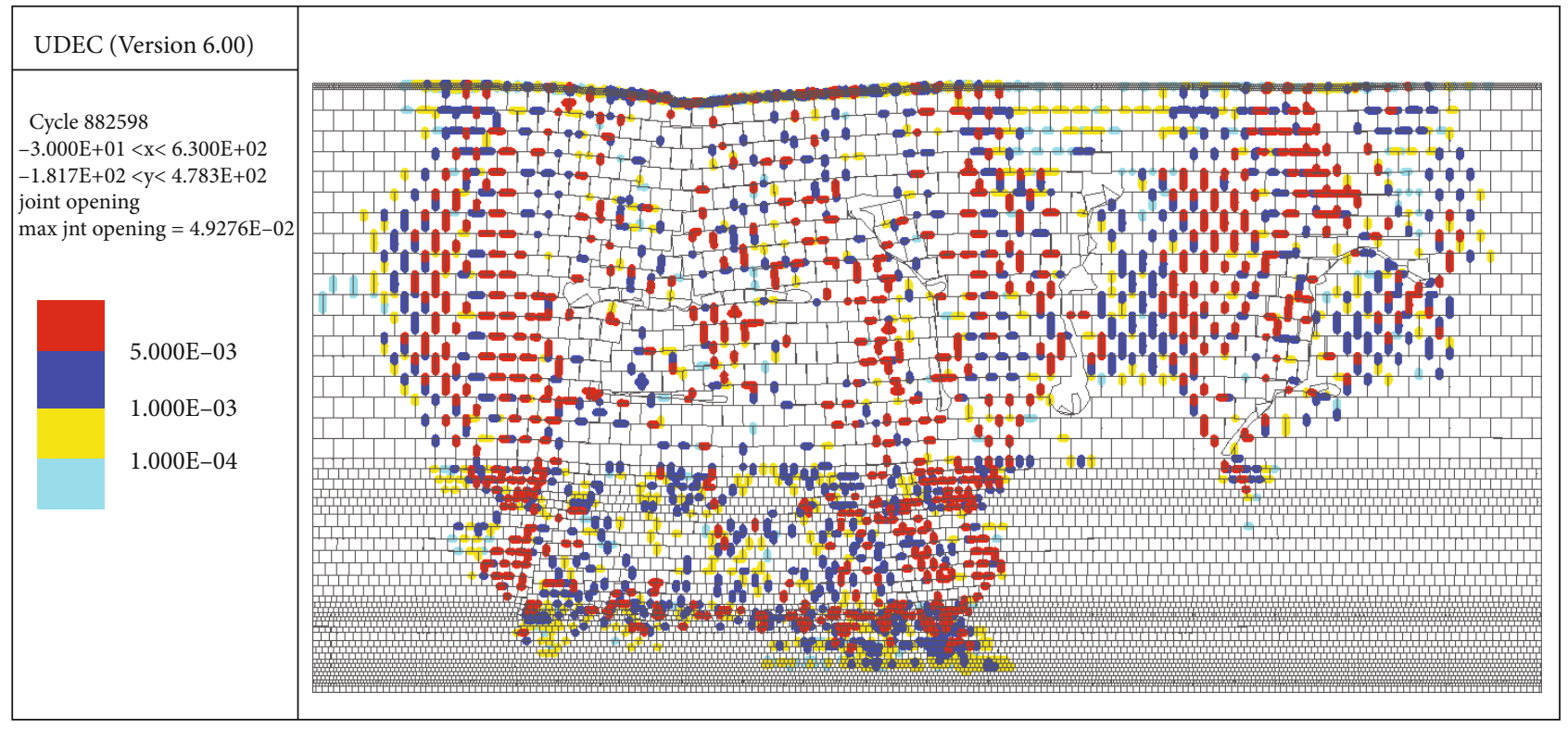

Figure 7: Mining-induced fracture field (mining distance is $320 \mathrm{~m}$ in 4\# coal seam).

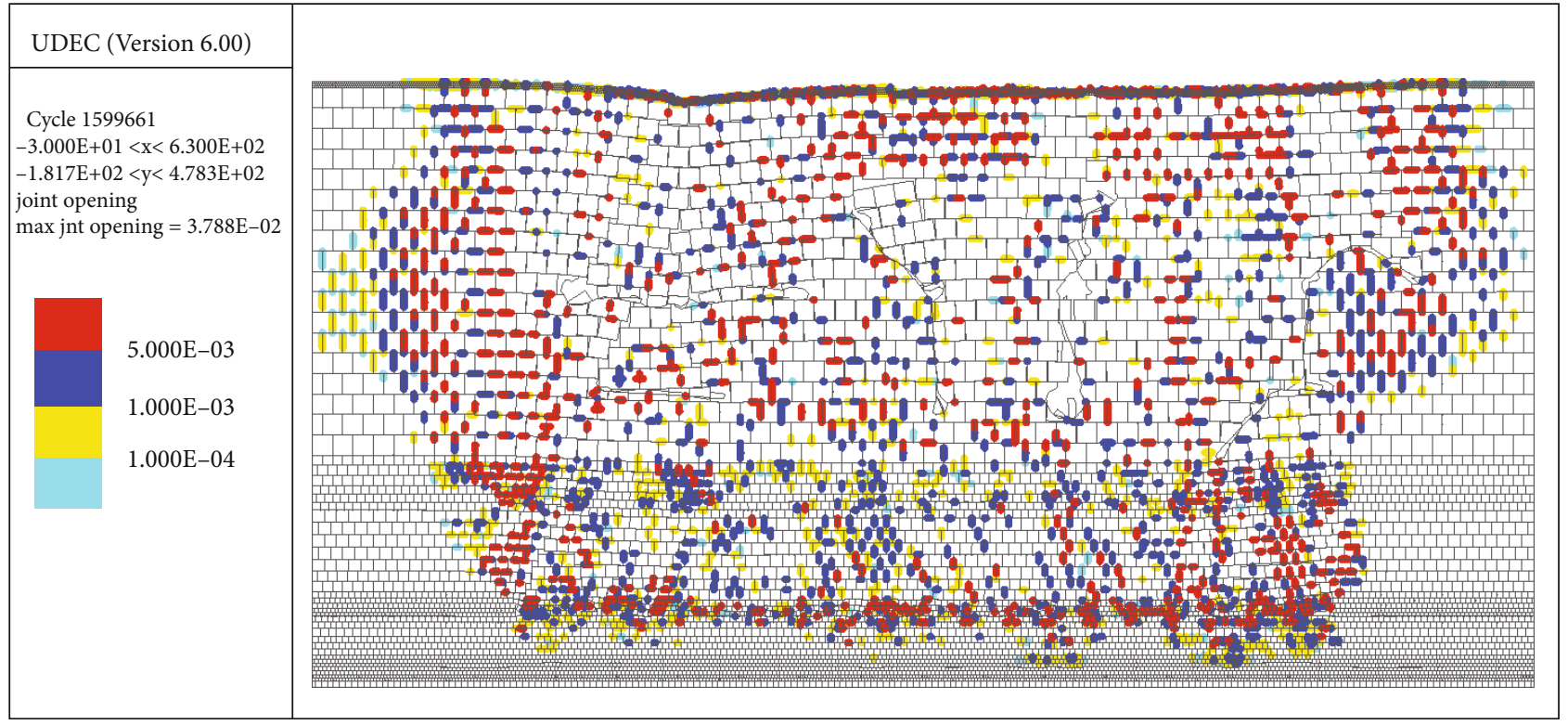

FIGURE 8: Mining-induced fracture field (mining distance is $500 \mathrm{~m}$ in $4 \#$ coal seam).

overburden fractures in 1 \# cave develop up to the surface, and the overburden fractures in $2 \#$ cave connect downward to the working face, forming a water inrush passage from the surface to the working face through $1 \#$ cave and $2 \#$ cave. Meanwhile, the opening degree of secondary development fractures in 3\# cave is mainly $1 \mathrm{~mm}-5 \mathrm{~mm}$, and the opening degree of secondary development fractures in $4 \#$ cave is mainly $0.1 \mathrm{~mm}-1 \mathrm{~mm}$, and the overlying rock fractures of 5\# cave basically have no secondary development. Therefore, when the working face in $4 \#$ coal seam advances from $100 \mathrm{~m}$ to $180 \mathrm{~m}$, the water in the aquifer flows into the working face through the vertical water inrush passage.

When the working face in $4 \#$ coal seam advances to $320 \mathrm{~m}$, the mining-induced fracture field is shown in
Figure 7. The maximum opening of the overburden fracture is $49.27 \mathrm{~mm}$. The fractures in the roof are mainly concentrated at the front and rear ends of the stope, and the opening degree is mainly greater than $5 \mathrm{~mm}$. The fractures in the bottom of the working face are mainly $1 \mathrm{~mm}-5 \mathrm{~mm}$, and the bottom of the gob is mainly $0.1 \mathrm{~mm}-1 \mathrm{~mm}$. After the collapsed rock mass in the mined-out area is compacted, the fracture opening is mainly greater than $1 \mathrm{~mm}$. As the working face advances, the mining-induced fractures in the roof form after the basic roof collapsed periodically, decrease from greater than $5 \mathrm{~mm}$ to $1 \mathrm{~mm}-5 \mathrm{~mm}$, and finally compacted to $0.1 \mathrm{~mm}-1 \mathrm{~mm}$.

Specifically, the fractures in 3\# cave develop upward to the surface and connect downward to the working face, 


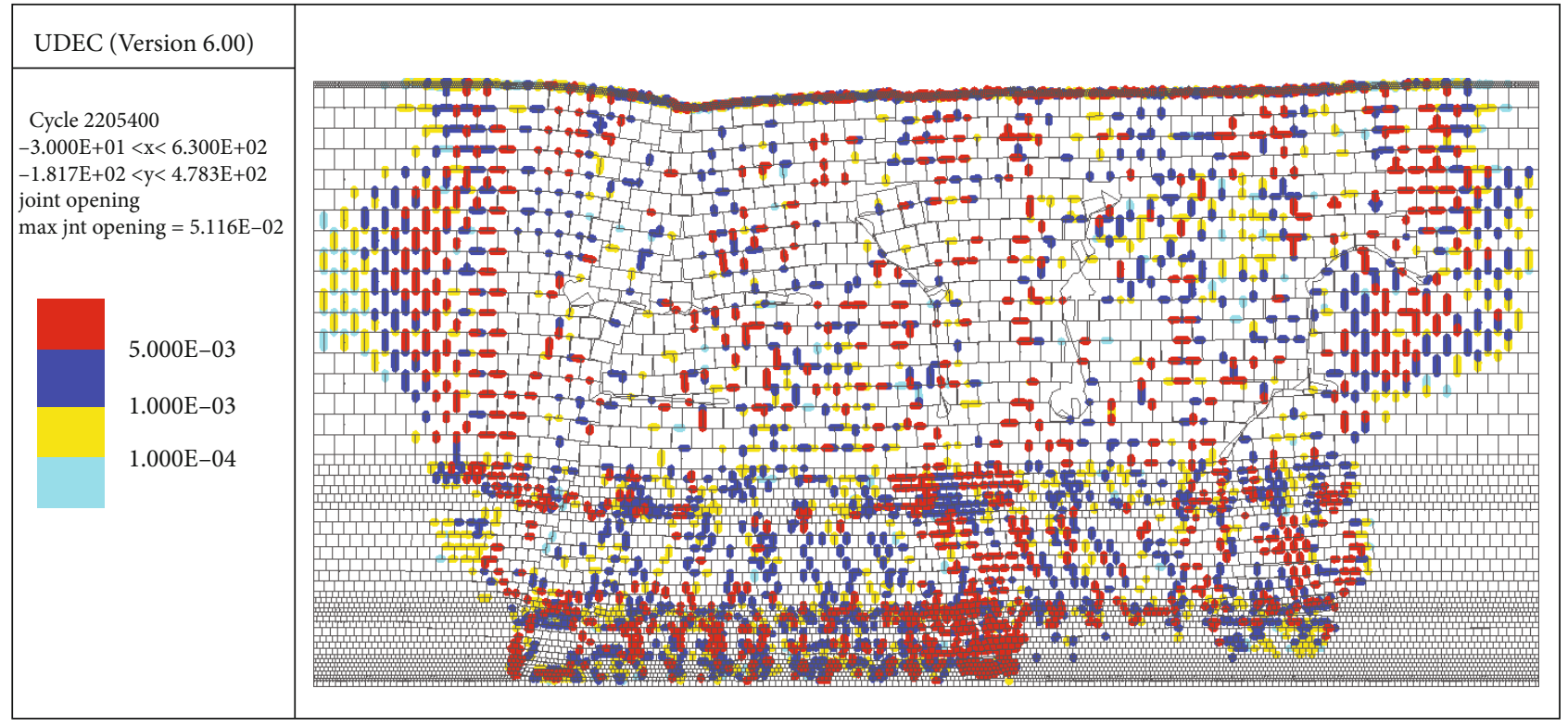

FIgURE 9: Mining-induced fracture field (mining distance is $340 \mathrm{~m}$ in 9\# coal seam).

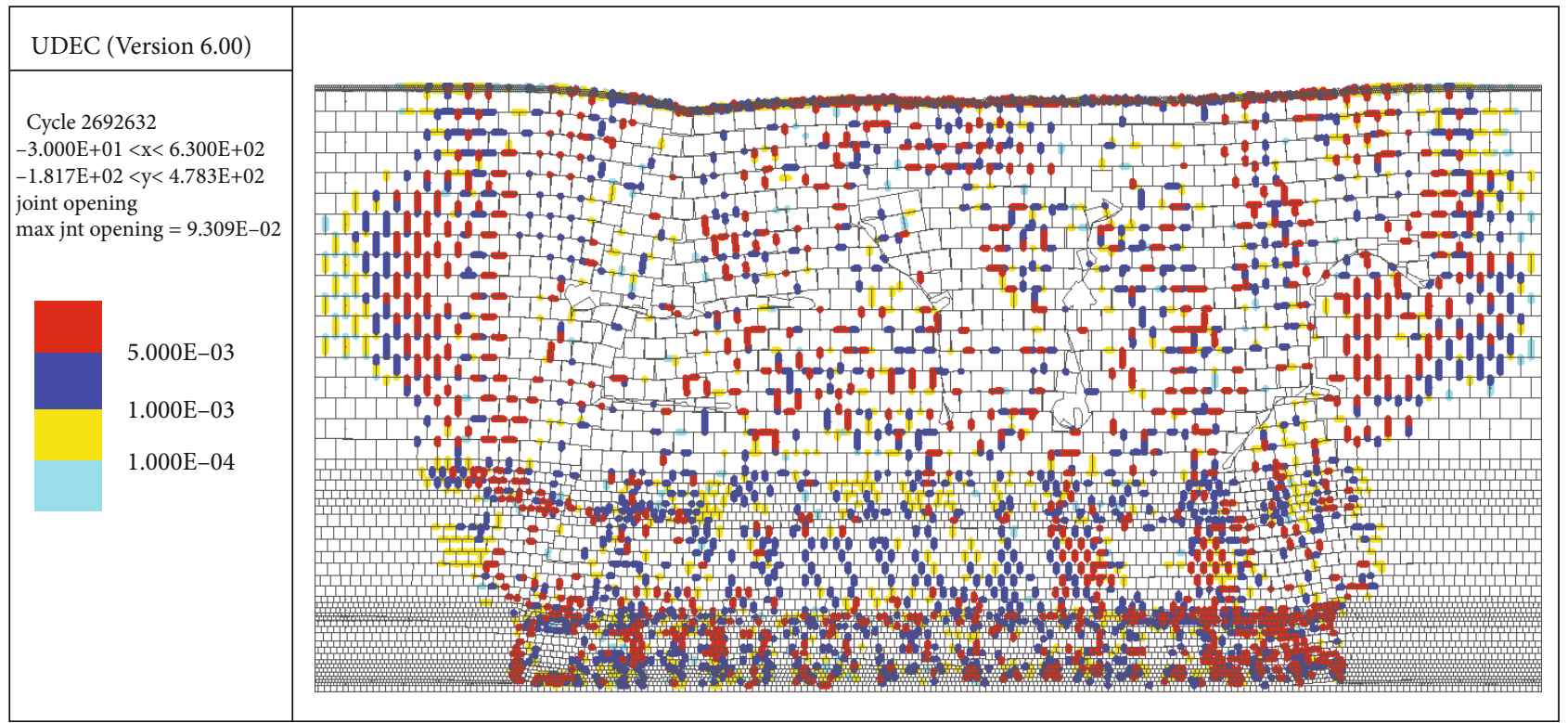

Figure 10: Mining-induced fracture field (mining distance is $500 \mathrm{~m}$ in 9\# coal seam).

forming a water inrush passage connecting the $3 \#$ cave to the surface and the working face. Meanwhile, 1\# cave, 3\# cave, and $4 \#$ cave are connected through the secondary developed fractures in the overburden. The opening degree of the secondary developed fractures of $4 \#$ cave has increased from $0.1 \mathrm{~mm}-1 \mathrm{~mm}$ to $1 \mathrm{~mm}-5 \mathrm{~mm}$ and greater than $5 \mathrm{~mm}$.

When the working face in $4 \#$ coal seam advances to $500 \mathrm{~m}$, the mining-induced fracture field is shown in Figure 8. The maximum opening of the overburden fracture is $37.88 \mathrm{~mm}$. The fractures in the overlying roof are mainly concentrated at the front and rear ends of the stope, especially at the working face, and the fracture opening is mainly greater than $5 \mathrm{~mm}$. The fractures on the bottom of the working face are mainly $1 \mathrm{~mm}-5 \mathrm{~mm}$, while the fractures on the bottom of the working face are mainly $0.1 \mathrm{~mm}-1 \mathrm{~mm}$ after the compaction of the collapsed rock. The fractures on the collapsed rock are mainly $1 \mathrm{~mm}-5 \mathrm{~mm}$ and greater than $5 \mathrm{~mm}$. As the working face advances, the opening of the fractures in the roof after the collapse of the basic roof is mainly greater than $5 \mathrm{~mm}$, and the compaction closure is $1 \mathrm{~mm}-5 \mathrm{~mm}$.

Specifically, the overburden fractures in $4 \#$ cave and 5\# cave develop up to the surface and connect downward to the working face, forming a water inrush passage connecting $4 \#$ cave and $5 \#$ cave to the surface and working face, respectively. Meanwhile, 4\# cave and 5\# cave are connected by secondary developed fractures, and the opening of the overburden fracture at the upper right of $5 \#$ cave has increased from $1 \mathrm{~mm}-5 \mathrm{~mm}$ to greater than $5 \mathrm{~mm}$. When the $4 \#$ coal 
seam is mined, the overlying karst caves are formed with transverse intersecting fractures. The secondary developed fractures of the karst caves develop upward to the surface and connect downward to the stope, forming the good water inrush passages in the overburden.

3.2. Mining-Induced Fracture Field in 9\# Coal Seam. The mining of $9 \#$ coal seam starts after $4 \#$ coal seam in downward mining. When the working face in $9 \#$ coal seam advances to $340 \mathrm{~m}$, the mining-induced fracture field is shown in Figure 9. The maximum opening of the overburden fractures is $51.16 \mathrm{~mm}$. The fractures in the roof are mainly caused by the periodic breaking and falling of the basic roof, connected with the floor fractures of $4 \#$ coal seam. The opening of the fractures is more than $5 \mathrm{~mm}$, forming the water inrush passage from the gob in $4 \#$ coal seam to the working face in 9\# coal seam.

Specifically, as the working face advances, the opening of fracture in the roof after collapse of the basic roof periodically is mainly greater than $5 \mathrm{~mm}$, and the compaction closure is mainly $1 \mathrm{~mm}-5 \mathrm{~mm}$. The fractures in the gob floor are mainly $0.1 \mathrm{~mm}-1 \mathrm{~mm}$, and the fracture opening of the collapsed rock mass in the gob is mainly $1 \mathrm{~mm}-5 \mathrm{~mm}$ and greater than $5 \mathrm{~mm}$.

When the working face in 9\# coal seam advances to $500 \mathrm{~m}$, the mining-induced fracture field is shown in Figure 10. The maximum opening of the overburden fracture is $93.09 \mathrm{~mm}$. The fractures in the roof are mainly caused by the periodic breaking and falling of the basic roof, connected with the floor fractures in $4 \#$ coal seam. The opening of the fractures is greater than $5 \mathrm{~mm}$, forming the water inrush passage from the gob in $4 \#$ coal seam to the working face in $9 \#$ coal seam.

Specifically, with the advance of working face, the opening of mining-induced fracture in the roof is greater than $5 \mathrm{~mm}$, and the compaction closure is $1 \mathrm{~mm}-5 \mathrm{~mm}$. The opening of fractures on the main floor is $0.1 \mathrm{~mm}-1 \mathrm{~mm}$, while those of collapsed rock mass in the gob are $1 \mathrm{~mm}-5 \mathrm{~mm}$ and greater than $5 \mathrm{~mm}$. The working face in 9\# coal seam has little effect on the evolution of water inrush passage induced by karst caves in the overburden.

\section{Conclusions}

(1) The cavities in the overburden reduce the periodic weighting step of the working face. On the one hand, the caves accelerate the breakage of the overburden; on the other hand, the caves intensify the development of the overburden fractures and form ultrahigh water inrush passage in the overburden. The karst caves in the overburden hydraulic fracture zone are strongly affected by mining, and the fracture opening at the cave is larger than that of the intact rock layer

(2) Karst caves in the overburden play a guiding role in the direction of fracture development and water inflow passage formation. The water inflow passage develops from bottom to top, and when it develops to a certain height, it expands towards the karst caves and, finally, leads to the karst caves. When the fractures are sufficiently developed, the conductive fractures tend to be formed between two caves. The secondary developed fractures of karst caves develop upward to the surface and connect downward to the stope

(3) The water inrush passage is formed with the Yulongshan limestone caves by the influence of the working face. The caves are connected to surface waterfall holes and trap pits, and atmospheric precipitation recharges the water in the caves. The overlying rock is subjected to periodic breakage. The cavern is connected to the lower overburden hydraulic fractures and forms a hydraulic passage with the surrounding trap pillars, eventually forming a water inrush passage between the working face and the karst caves

\section{Data Availability}

The data used to support the findings of this study are included within the article.

\section{Conflicts of Interest}

The authors declare that they have no conflicts of interest.

\section{Acknowledgments}

This work was supported by the National Natural Science Foundation of China (51774110, 41972175, 52004082), the Strategic Consulting Research Project of Henan Institute for China Engineering Science and Technology Development Strategy (2021HENZT03), the Natural Science Foundation of Henan Province (202300410170), and the Fundamental Research Funds for the Universities of Henan Province (NSFRF200302).

\section{References}

[1] S. C. Li, K. Wang, L. P. Li, Z. Q. Zhou, S. S. Shi, and S. Liu, "Mechanical mechanism and development trend of waterinrush disasters in karst tunnels," Chinese Journal of Theoretical and Applied Mechanics, vol. 49, no. 1, pp. 22-30, 2017.

[2] L. Y. Yu, L. J. Han, J. L. Ran, S. Q. Yang, and C. M. Zheng, "Comprehensive geological prediction of filling cavity and treatment of mud inrush for yangling tunnel," Journal of Basic Science and Engineering, vol. 24, no. 6, pp. 1256-1267, 2016.

[3] M. Q. Zhang, Q. Y. Zeng, and B. Yang, "Water release mechanism of caverns of karst tunnels and case studies," Chinese Journal of Geotechnical Engineering, vol. 32, no. 10, pp. 1543-1550, 2010.

[4] Y. Xue, J. Liu, P. G. Ranjith, X. Liang, and S. Wang, "Investigation of the influence of gas fracturing on fracturing characteristics of coal mass and gas extraction efficiency based on a multi-physical field model," Journal of Petroleum Science and Engineering, vol. 206, article 109018, 2021.

[5] Z. Z. Cao, P. Xu, Z. H. Li, M. X. Zhang, Y. Zhao, and W. L. Shen, "Joint bearing mechanism of coal pillar and backfilling body in roadway backfilling mining technology," CMC-Computers Materials \& Continua, vol. 54, no. 2, pp. 137-159, 2018. 
[6] H. X. Lin, F. Yang, Z. Z. Cao, Y. Wang, and X. J. Jiao, "Disastrous mechanism of water discharge in abandoned gob above the stope in mining extra-thick coal seam," Geofluids, vol. 2021, 2021.

[7] Y. Xue, J. Liu, F. Dang, X. Liang, S. Wang, and Z. Ma, "Influence of $\mathrm{CH} 4$ adsorption diffusion and $\mathrm{CH} 4$-water two-phase flow on sealing efficiency of caprock in underground energy storage," Sustainable Energy Technologies and Assessments, vol. 42, article 100874, 2020.

[8] B. H. Yao, Z. W. Chen, J. P. Wei, T. H. Bai, and S. M. Liu, "Predicting erosion-induced water inrush of karst collapse pillars using inverse velocity theory," Geofluids, vol. 2018, 2018.

[9] Z. W. Liu, M. C. He, and S. R. Wang, "Study on karst waterburst mechanism and prevention countermeasures in yuanliangshan tunnel," Rock and Soil Mechanics, vol. 27, no. 2, pp. 228-232, 2006.

[10] Y. L. Zhao, S. G. Zhang, W. Wan, W. J. Wang, L. Cai, and Q. Y. Peng, "Solid-fluid coupling-strength reduction method for karst cave water inrush before roadway based on flow state conversion theory," Chinese Journal of Rock Mechanics and Engineering, vol. 33, no. 9, pp. 1852-1862, 2014.

[11] Y. Jiao and H. B. Bai, "Mechanism of delayed groundwater inrush from covered karst cave in coal seam floor," Journal of China Coal Society, vol. 38, no. s2, pp. 377-382, 2013.

[12] Y. L. Zhao, P. Cao, W. Wan, W. J. Wang, S. G. Zhang, and S. H. Zou, "Fluid-solid coupling analysis of water bursting catastrophe from concealed confined karst cave before roadway," Journal of Central South University (Science and Technology), vol. 45, no. 5, pp. 1598-1604, 2014.

[13] C. Q. Zhu, Y. J. Huang, Z. Zhou, and Z. Q. Zhang, “The karst cave detection and its collapse generalized model under the effects of mining in huping coal mine," Journal of Hunan University of Science \& Technology (Natural Science Edition), vol. 33, no. 4, pp. 7-13, 2018.

[14] D. D. Pan, S. C. Li, Z. H. Xu et al., "Model tests and numerical analysis for water inrush caused by karst caves filled with confined water in tunnels," Chinese Journal of Geotechnical Engineering, vol. 40, no. 5, pp. 828-836, 2018.

[15] Z. J. Wang, J. Y. Gao, P. Zhang, X. Guan, and X. F. Ji, “Stability analysis of tunnel face in high-pressure karst tunnels based on catastrophe theory," Chinese Journal of Geotechnical Engineering, vol. 41, no. 1, pp. 95-103, 2019.

[16] C. Q. Zhu, D. G. Cui, Z. Zhou, Q. F. Li, and Y. J. Huang, "Similar simulation of mining-induced fissure development law and cave destruction character when mining in karst area," Chinese Journal of Underground Space and Engineering, vol. 15, no. 1, pp. 93-100, 2019.

[17] Y. Xue, P. G. Ranjith, F. Dang et al., "Analysis of deformation, permeability and energy evolution characteristics of coal mass around borehole after excavation," Natural Resources Research, vol. 29, no. 5, pp. 3159-3177, 2020.

[18] Z. Z. Cao, F. Du, Z. H. Li, Q. T. Wang, P. Xu, and H. X. Lin, "Research on instability mechanism and type of ore pillar based on the fold catastrophe theory," CMES-Computer Modeling in Engineering \& Science, vol. 113, no. 3, pp. 287306, 2017.

[19] W. L. Shen, J. B. Bai, W. F. Li, and X. Y. Wang, "Prediction of relative displacement for entry roof with weak plane under the effect of mining abutment stress," Tunnelling and Underground Space Technology, vol. 71, pp. 309-317, 2018.
[20] Y. Xue, F. Gao, Y. N. Gao, X. Liang, Z. Z. Zhang, and Y. Xing, "Thermo-hydro-mechanical coupled mathematical model for controlling the pre-mining coal seam gas extraction with slotted boreholes," International Journal of Mining Science and Technology, vol. 27, no. 3, pp. 473-479, 2017.

[21] Y. Xue, T. Teng, F. Dang, Z. Ma, S. Wang, and H. Xue, "Productivity analysis of fractured wells in reservoir of hydrogen and carbon based on dual-porosity medium model," International Journal of Hydrogen Energy, vol. 45, no. 39, pp. 20240-20249, 2020.

[22] Z. Z. Cao, Y. L. Ren, Q. T. Wang, B. H. Yao, and X. C. Zhang, "Evolution mechanism of water-conducting channel of collapse column in karst mining area of Southwest China," Geofluids, vol. 2021, 2021. 